\title{
Pengaruh Level Ampas Tahu terhadap Deposisi Lemak Entok Umur 10 Minggu
}

\author{
Adilamen Mabihastu Akbar, Warnoto, Tris Akbarillah*
}

Jurusan Peternakan, Fakultas Pertanian, Universitas Bengkulu

Jalan W. R Supratman, Kandang Limun, Bengkulu, 38371 A

*Korespondensi: trisakbarillah@yahoo.co.id

Artikel ini diterima (received): 3 Februari 2020; dinyatakan disetujui (accepted): 6 April 2020; terbit (published): 15 Mei 2020. Artikel ini dipublikasi secara daring pada https://ejournal.unib.ac.id/index.php/buletin_pt

\section{ABSTRAK}

Penelitian ini bertujuan untuk mengevaluasi pemberian level ampas tahu terhadap deposisi lemak entok umur 10 minggu dengan campuran berupa pakan dengan level ampas tahu yang berbeda yaitu 30\%, 35\%, dan 40\%. Penelitian menggunakan Rancangan Acak Lengkap (RAL) terdiri 4 perlakuan, yaitu $\mathrm{PO}=0 \%, \mathrm{P} 1=30 \%, \mathrm{P} 2=35 \%$ dan $\mathrm{P} 3=40 \%$ menggunakan ampas tahu dengan level pemberian yang berbeda. Hasil analisis ragam menunjukkan bahwa pemberian ampas tahu level $30 \%, 35 \%$ dan $40 \%$ berpengaruh nyata $(P<0,01)$ terhadap lemak leher, lemak paha, lemak jantung, lemak gizzard, lemak abdomen dan lemak total. Dapat disimpulkan penggunaan ampas tahu sampai dengan level $40 \%$ menurunkan lemak leher, lemak paha, lemak gizzard, lemak jantung, lemak abdominal dan lemak total.

Kata kunci : Ampas tahu, entok, deposisi lemak

\section{PENDAHULUAN}

Entok termasuk dalam ordo Anseriformes, Famili Anatidae, genus Cairina dan spesies Moschata (Damayanti, 2006). Entok merupakan itik pedaging yang paling besar dan bobotnya bisa mencapai $3,5 \mathrm{~kg}$ (Tanwiriah et al., 2006). Selama ini entok dimanfaatkan sebagai penghasil telur dan sebagai sarana pengeram telur itik dan ayam, padahal entok dapat dimanfaatkan sebagai unggas penghasil daging. Persentase karkas entok dengan berat hidup $3,75 \mathrm{~kg}$ adalah 62,6\% (Mega et al., 2008).

$\mathrm{Di}$ Indonesia pertumbuhan entok agak lambat karena cara pemeliharaannya yang kurang baik. Salah satu upaya peningkatan produksi dapat ditempuh melalui cara pemeliharaan yang intensif, tetapi kendalanya biaya ransum yang mahal. Ransum merupakan factor yang paling berpengaruh pada pertumbuhan ternak, selain itu biaya ransum sangat besar yaitu sekitar $60-70 \%$ dari biaya produksi. Dalam rangka menurunkan biaya ransum, maka sebaiknya menggunakan bahan pakan alternatif dari sumber daya lokal yaitu ampas tahu dengan keunggulan harganya murah, serta mengandung nutrisi yang baik (Tanwiriah et al., 2006).

Ampas tahu kering mengandung protein kasar 22,64\%, lemak kasar 6,12\%, serat kasar 22,65\%, abu 2,62\%, kalsium 0,04\%, fosfor 0,06\%, dan Gross Energi 4010 $\mathrm{kkal} / \mathrm{kg}$ (Tanwiriah et al., 2006). Kandungan nutrisi ampas tahu cukup tinggi tetapi kandungan airnya juga tinggi yang tidak dapat disimpan dalam waktu yang lama. Agar dapat disimpan dalam waktu yang lebih lama ampas tahu perlu dikeringkan terlebih dahulu (Hernaman et al., 2005)

Persentase lemak abdomen untuk ayam broiler berkisar $0,50 \%-0,61 \%$, semakin tinggi penambahan ampas tahu dan dedak fermentasi dalam ransum, ada kecenderungan menurunkan persentase lemak abdomen ayam broiler (Mahata et al., 2008). Hal ini disebabkan kandungan serat kasar dalam ransum yang semakin meningkat dengan penambahan ampas tahu dan dedak fermentasi selama penelitian (Sandi et al., 2012).

Untuk mencerna serat kasar dibutuhkan energi yang banyak sehingga ayam tidak memiliki energi yang berlebihan untuk disimpan dalam bentuk lemak daging 
(Mahfudz, 2000). Pemberian pakan yang berserat kasar tinggi pada ayam pedaging mampu menurunkan kadar lemak karkas (Suparjo et al., 2003). Dari keterangan dan literatur diatas maka diadakannya penelitian ini dengan harapan ampas tahu dapat menurunkan deposisi lemak entok. Penelitian ini bertujuan untuk mengetahui pengaruh penggunaan level ampas tahu yang berbeda terhadap deposisi lemak entok (Muscovy duck) umur 10 minggu.

\section{MATERI DAN METODE Persiapan pakan}

Persiapan pakan dimulai dengan menyiapkan ampas tahu. Hal pertama yang dilakukan membeli ampas tahu di pabrik tahu yang ada di Bengkulu. Setelah mendapatkan ampas tahu, kemudian ampas tahu diperas menggunakan kain dengan tujuan pengeringan (mengurangi kadar air yang terdapat dalam ampas tahu tersebut). Setelah diperas, ampas tahu diletakkan di atas plastik besar untuk dilakukan pengerigan. Pengeringan dilakukan dengan cara alami yaitu pengeringan menggunakan sinar matahari. Proses pengeringan dilakukan selama \pm 3 hari sampai ampas tahu tersebut benar-benar kering.

Tujuan dari pengeringan ampas tahu yaitu, mengawetkan ampas tahu dan membuatnya tahan lama dan bila pada saat penelitian ampas tahu basah tidak tersedia sehingga ampas tahu bisa disimpan dalam jangka waktu yang cukup lama sampai beberapa bulan (bila ampas tahu benar-benar kering). Setelah persiapan ampas tahu selesai, maka mempersiapkan bahan pakan lain berupa jagung, dedak, konsentrat dan minyak. Setelah semua bahan pakan siap, maka pakan tersebut diformulasikan.

\section{Persiapan kandang}

Kandang yang digunakan dalam penelitian ini adalah kandang individu terdiri dari petak-petak sebanyak 64 buah. Dan setiap petak diisi dengan 1 ekor entok, dengan total entok yang digunakan sebanyak 64 ekor, dan setiap petak yang ada dilengkapi dengan paralon panjang dan saling terhubung yang digunakan sebagai tempat pakan dan tempat minum entok yang diletakkan di sepanjang bagian kandang entok tersebut. Sebelum melakukan penelitian, memperbaiki bagian kandang yang rusak sebagai tempat pemeliharaan entok, dan setelah itu kandang entok dibersihkan mulai dari tempat pakan, tempat minum dan lantai bawah. Kemudian kandang disemprot dengan desinfektan untuk membunuh bakteri yang ada di dalam kandang.

\section{Pemeliharaan DOD}

DOD yang baru datang diberi air putih atau air dengan campuran gula yang digunakan untuk mengembalikan tenaga DOD yang habis ketika dalam perjalanan. DOD umur 0-2 minggu diberi pakan komersial berupa BR1, karena entok starter memerlukan Protein Kasar sebesar 22\% dan Energi Metabolik sebesar 2.900 (kkal/kg) (NRC, 1994). Setelah DOD berumur 3-10 minggu pakan yang diberikan berupa ransum perlakuan yaitu ampas tahu, dedak, jagung, minyak dan konsentrat yang diformulasikan menjadi 4 perlakuan setiap perlakuan terdiri 16 ulangan. Setiap ulangan terdiri dari 1 ekor entok. Pemberian minum dilakukan secara adlibitum atau secara terus menerus sedangkan pakan diberikan sehari 2 kali (pagi dan sore). Entok ditimbang setiap minggu sekali untuk mengetahui performans entok setiap minggu. Kebutuhan ransum didasarkan pada kebutuhan nutrisi itik peking (NRC, 1994.) Tabel 1 adalah pemberian pakan penelitian menurut (Fitriyanto, 2007) dengan penambahan $10 \%$ dari pakan yang diberikan.

Tabel 1. Konsumsi pakan entok

\begin{tabular}{cc}
\hline \hline Umur (minggu) & (gram/ekor/minggu) \\
\hline 1 & 150 \\
2 & 310 \\
3 & 400 \\
4 & 610 \\
5 & 780 \\
6 & 800 \\
7 & 950 \\
8 & 1000 \\
\hline
\end{tabular}

\section{Penyusunan ransum}

Ransum yang diberikan dalam penelitian ini adalah ransum BR1 pada umur 0-2 minggu dan ransum yang disusun (diformulasikan) untuk entok umur 3-10 minggu sesuai dengan pakan perlakuan. Bahan yang digunakan untuk menyusun ransum terdiri dari ampas tahu, jagung, dedak, konsentrat dan minyak (Tabel 2).

\section{Rancangan percobaan}

Penelitian ini menggunakan Rancangan Acak Lengkap (RAL), dengan empat (4) perlakuan dan 16 ulangan. Setiap ulangan terdiri atas 1 ekor entok sehingga entok yang 
diperlukan sebanyak 64 ekor. Adapun perlakuannya adalah sebagai berikut :

PO : Pakan dengan ampas tahu 0\% (Tanpa ampas tahu)

P1 : Pakan dengan ampas tahu $30 \%$

P2 : Pakan dengan ampas tahu $35 \%$

P3 : Pakan dengan ampas tahu $40 \%$

Variabel yang diukur meliputi lemak leher, lemak paha, lemak abdomen, lemak gizzard, lemak jantung, dan jumlah lemak total.

Tabel 2. Formulasi ransum dan kandungan nutrisi ransum perlakuan umur 3-10 Minggu

\begin{tabular}{|c|c|c|c|c|}
\hline \multirow{2}{*}{$\begin{array}{c}\text { Bahan Pakan } \\
(\%)\end{array}$} & \multicolumn{4}{|c|}{ Perlakuan } \\
\hline & $\mathrm{PU}$ & $\mathrm{PI}$ & $\mathrm{PL}$ & $\mathrm{P3}$ \\
\hline Ampas Tahu & 0 & 30 & 35 & 40 \\
\hline Jagung & 42 & 33 & 31 & 29,5 \\
\hline Dedak & 31 & 25 & 24,6 & 23,6 \\
\hline $\begin{array}{l}\text { Konsentrat } \\
\text { Broiler }\end{array}$ & 24 & 9 & 6,4 & 3,9 \\
\hline Minyak & 3 & 3 & 3 & 3 \\
\hline Total (\%) & 100 & 100 & 100 & 100 \\
\hline PK (\%) & 16,07 & 16,10 & 16,08 & 16,08 \\
\hline EM (Kkal/kg) & 3.010 & 3.007 & 3.001 & 3.000 \\
\hline Са (\%) & 0,99 & 0,47 & 0,39 & 0,30 \\
\hline P (\%) & 0,49 & 0,57 & 0,58 & 0,59 \\
\hline SK (\%) & 9,53 & 12,67 & 13,30 & 13,82 \\
\hline LK (\%) & $\underline{4,39}$ & $\underline{5,70}$ & $\underline{5,94}$ & $\underline{6,16}$ \\
\hline
\end{tabular}

\section{Analisis data}

Data dianalisa secara statistik dengan menggunakan Sidik ragam (ANOVA) berdasarkan rancangan yang digunakan. Jika terdapat perbedaan yang nyata antar perlakuan dilakukan dengan uji Duncan's Multiple Range (DMRT) untuk melihat perbedaan antar perlakuan.

\section{HASIL DAN PEMBAHASAN \\ Lemak leher}

Hasil sidik ragam menunjukkan bahwa perlakuan pemberian ampas tahu kering dalam level berbeda dan pengaruh nyata $(P<0,01)$ terhadap lemak leher. Hasil uji lanjut menunjukkan bahwa pemberian ampas tahu 30\% (P1) berbeda tidak nyata dengan P0 (tanpa penambahan ampas tahu). Sedangkan perlakuan P0 dan P1 berbeda nyata $(P<0,01)$ dengan P2 dan P3, sedangkan P2 dan P3 tidak berbeda nyata. Hal ini menunjukkan bahwa pemberian ampas tahu kering pada level P2 (35\%) dan P3 (40\%) dapat menurunkan persentase lemak leher entok, sekaligus dengan penurunan berat badan disetiap perlakuan yang diberi ampas tahu. Hal ini sesuai dengan pendapat Trisnadewi et al (2000), bahwa di dalam ampas tahu terdapat kandungan arabinoxylan yang menyebabkan daya cerna unggas terhambat akibatnya terbentuk gel kental dalam usus halus yang menyebabkan penyerapan energi dan lemak terhambat sehingga deposisi lemak menjadi rendah.

\section{Lemak paha}

Hasil sidik ragam menunjukkan bahwa perlakuan pemberian ampas tahu kering dengan level berbeda berpengaruh nyata $(P<0,01)$ terhadap lemak paha entok. Hasil uji lanjut menunjukkan bahwa persentase lemak paha P0 tidak berbeda nyata terhadap P1, dan persentase lemak P0 dan P1 lebih tinggi dibandingkan P2 dan P3.Persentase lemak P2 dan P3 tidak berbeda nyata. Hasil penelitian ini menunjukkan bahwa pemberian ampas tahu menyebabkan terjadinya penurunan lemak paha. Lemak paha terendah hingga tertinggi dihasilkan perlakuan P3, P2, P1, dan P0, penurunan lemak tersebut juga diikuti dengan penurunan berat badan entok disetiap perlakuan yang diberi ampas tahu. Penelitian ini sejalan dengan hasil yg didapatkan Mahata et al (2008) semakin tinggi penambahan ampas tahu dalam ransum, semakin tinggi penurunan persentase lemak ayam broiler. Hal yang serupa juga diungkapkan Suparjo et al (2003) bahwa pemberian pakan berserat tinggi pada ayam pedaging mampu menurunkan kadar lemak karkas. Menurut Sutardi (1997), serat kasar yang tinggi menyebabkan penurunan kecernaan energi dan penyerapan lemak, sehingga pertambahan berat badan itik menurun.

\section{Lemak jantung}

Hasil sidik ragam menunjukkan bahwa perlakuan pemberian ampas tahu kering level berbedaberpengaruh nyata $(P<0,01)$ terhadap lemak jantung. Hasil uji lanjut menunjukkan bahwa perlakuan tanpa ampas tahu (PO) berbeda nyata terhadap P2 dan P3. P1 (ampas tahu 30\%) berbeda nyata terhadap P2 dan P3, sedangkan perlakuan P2 dan P3 tidak berbeda nyata.Hal ini dikarenakan keberadaan serat kasar yang tinggi dalam ransum mampu mengikat asam empedu, asam empedu berfungsi untuk menyerap makanan berlemak sehingga mudah dihidrolisis oleh enzim lipase (Bintang et al., 1998). Joseph et al (2002), menyatakan rendahnya persentase lemak pada ternak itik yang mendapat tambahan serat ini diakibatkan absorbsi asam-asam lemak yang berasal dari ransum menurun. 
Tabel 3. Hasil penelitian pengaruh pemberian ampas tahu terhadap lemak entok umur 10 minggu

\begin{tabular}{|c|c|c|c|c|}
\hline \multirow{2}{*}{ Persentase Lemak } & \multicolumn{4}{|c|}{ Perlakuan } \\
\hline & $\begin{array}{c}\mathrm{PO} \\
(0 \% \text { ampas tahu) }\end{array}$ & $\begin{array}{c}\mathrm{P} 1 \\
(30 \% \text { ampas tahu) }\end{array}$ & $\begin{array}{c}\text { P2 } \\
\text { (35\% ampas tahu) }\end{array}$ & $\begin{array}{c}\text { P3 } \\
\text { (40\% ampas tahu) }\end{array}$ \\
\hline Leher $\quad(\%)$ & $0,16^{a}$ & $0,12^{\mathrm{a}}$ & $0,01^{b}$ & $0,01^{b}$ \\
\hline Paha $\quad(\%)$ & $0,44^{\mathrm{a}}$ & $0,43^{a}$ & $0,18^{b}$ & $0,16^{b}$ \\
\hline Jantung $(\%)$ & $0,10^{a}$ & $0,09^{a}$ & $0,01^{b}$ & $0,01^{b}$ \\
\hline Gizzard (\%) & $0,20^{\mathrm{a}}$ & $0,18^{a}$ & $0,08^{b}$ & $0,06^{b}$ \\
\hline Abdomen (\%) & $0,55^{a}$ & $0,32^{a}$ & $0,07^{b}$ & $0,06^{b}$ \\
\hline $\begin{array}{l}\text { Jumlah Total variabel } \\
\text { Lemak yang diamati (\%) }\end{array}$ & $1,24^{a}$ & $1,22^{a}$ & $0,35^{b}$ & $0,33^{b}$ \\
\hline
\end{tabular}

Keterangan : Perlakuan berbeda nyata $(<0,01)$

\section{Lemak gizzard}

Hasil sidik ragam menunjukkan bahwa perlakuan pemberian ampas tahu kering dalam level yang berbeda menunjukkan berpengaruh nyata $(P<0,01)$ terhadap lemak gizzard. Hasil uji lanjut menunjukkan bahwa perlakuan tanpa ampas tahu P0 dan P1 berbeda tidak nyata, Menurut Bidura et al (1996) bahwa adanya serat kasar yang tinggi dalam ransum dapat menurunkan perlemakan dalam tubuh ternak ayam. Penurunan perlemakan yang disebabkan oleh kandungan serat kasar yang tinggi ini diikuti dengan penurunan berat badan entok disetiap perlakuan yang diberi ampas tahu, akan tetapi berbeda nyata terhadap P2 dan P3. Sedangkan P2 dan P3 tidak berbeda nyata. Hal ini dikarenakan serat kasar yang tinggi, serat kasar yang tinggi pada broiler atau unggas membutuhkan energi untuk mencerna sehingga tidak memiliki energi tersimpan dalam bentuk lemak daging (Sandi et al., 2012).

\section{Lemak abdomen}

Hasil sidik ragam menunjukkan perlakuan pemberian ampas tahu kering dengan level yang berbeda berpengaruh nyata $(P<0,01)$ terhadap lemak abdomen. Hasil uji lanjut menunjukkan bahwa perlakuan tanpa ampas tahu P0 tidak berbeda nyata terhadap P1, dan berbeda nyata terhadap P2 dan P3. Hal ini menunjukkan bahwa penambahan ampas tahu dapat menurunkan persentase lemak abdomen entok. Ini disebabkan oleh semakin tingginya kandungan serat kasar dalam ransum. Secara kuantitatif menunjukkan terjadinya penurunan lemak abdominal 0,23\%, 0,48\%, 0,49\% pada $\mathrm{P} 1$, P2, P3 dibandingkan dengan kontrol (tanpa ampas tahu), penurunan lemak ini juga diikuti dengan penurunan berat badan entok disetiap perlakuan yang diberi ampas tahu. Keadaaan ini sesuai dengan pendapat Erawati (1994) menyatakan bahwa persentase lemak abdominal menurun dengan semakin tingginya kandungan serat kasar dalam ransum. Hal ini juga didukung oleh pendapat Samudera dan Hidayatullah (2008) bahwa jumlah bantalan dan lemak abdomen itik menurun dengan semakin meningkatnya kandungan serat kasar dalam ransum.

\section{Lemak total}

Hasil sidik ragam menunjukkan bahwa perlakuan pemberian ampas tahu denganlevel berbeda berpengaruh nyata $(P<0,01)$ terhadap persentase lemak leher, lemak paha kiri dan kanan, lemak jantung, lemak gizzard dan lemak abdomen. Hasil uji lanjut menunjukkan bahwa penambahan ampas tahu perlakuan P2 dan P3 berbeda nyata terhadap P0, sedangkanPO tidak berbeda nyata dengan P1, sedangkan P2 tidak berbeda nyata terhadap P3.Keadaaan ini sesuai dengan pendapat (Mahfudz, 2000) untuk mencerna serat kasar dibutuhkan energi yang banyak sehingga ayam tidak memiliki energi yang berlebihan untuk disimpan dalam bentuk lemak daging. Hal ini juga didukung oleh pendapat Trisnadewi et al (2000), di dalam ampas tahu terdapat kandungan arabinoxylan yang menyebabkan terhambatnya daya cerna pada unggas karena arabinoxylan itu mengakibatkan terbentuknya gel kental dalam usus halus yang menyebabkan penyerapan energi dan lemak terhambat sehingga deposisi lemak menjadi rendah.Walaupun penurunan lemak terjadi pada setiap perlakuan akan tetapi, penurunan lemak tersebut juga diikuti dengan penurunan berat badan entok mulai 
dari P2, P3 dan P4. Hal ini terjadi karena ransum dalam penelitian sangat tinggi sehingga nilai cerna ransum sangat rendah.

\section{KESIMPULAN}

Hasil penelitian membuktikan bahwa penggunaan ampas tahu sampai dengan taraf 35\% menurunkan persentase lemak leher, lemak paha, lemak abdomen, lemak gizzard dan lemak jantung. Turunnya lemak juga diiringi dengan penurunan bobot badan entok disetiap perlakuan yang diberi ampas tahu.

\section{DAFTAR PUSTAKA}

Bidura I.G.N.G., I.D.G.A. Udayana, I.M. Suasta dan T.G.B. Yadhnya. 1996. Pengaruh Tingkat Serat Kasar Ransum Terhadap Produksi dan Kadar Kolestrol Telur Ayam. Denpasar. Laporan Penelitian Fakultas Peternakan Universitas Udayana, Bali.

Bintang I.A.K., A.P. Sinurat dan T. Murtisari. 1998. Penggunaan bungkil inti sawit dan produk fermentasinya dalam ransum itik sedang bertumbuh. JITV 4(3): 179-184.

Damayanti, A.P. 2006. Kandungan protein, lemak daging dan kulit itik, entok dan Mandalung umur 8 minggu. J. Agroland 13 (3): 313-317.

Erawati. 1994. Evaluasi penggunaan ampas tahu dalam ransum terhadap lemak abdominal, hati, jantung, ginjal, ampela, usus, dan caeca ayam pedaging. Tesis, Program Pasca Sarjana Institut Pertanian Bogor, Bogor

Fitriyanto, A. 2007. Pengaruh tingkat protein pakan dan frekuensi pemberian pakan terhadap kinerja entok (Cairina muschata) jantan starter. Skripsi. Jurusan Produksi Ternak Fakultas Peternakan Universitas Brawijaya. Malang.

Hernaman, I., R Hidayat dan Mansyur. 2005. Pengaruh penggunaan molases dalam pembuatan silase campuran ampas tahu dan pucuk tebu kering terhadap nilai ph dan komposisi zat-zat makanannya. Jurnal IImu Ternak. 5(2): 94-99.

Joseph, G., T.U. Harry, Rukmiasih, I. Wahyuni, S.Y. Randa, H. Hafid dan A. Parakarsih. 2002. Status kolestrol itik Mandalung dengan pemberian serat kasar dan Vitamin E. Seminar Teknologi Peternakan dan Veteriner. Laboratorium Nutrisi Ternak Daging dan Kerja. Fakultas Peternakan Institut Pertanian Bogor, Bogor.

Mahata, M.E., A. Dharma, I. Ryanto and Y. Rizal. 2008. Effect of substituting shrimp waste hydrolystate of penaeus merguensis for fish meal in broiler performance. Pak. J.Nutr. 7(6): 806-810

Mahfudz L.D. 2000. Efektivitas oncom tahu sebagai bahan pakan ayam broiler. Anim.Prod. 8(2).108-114.

Mega, O., D. Kaharuddin., Kususiyah dan Y. Fenita. 2008. Pengaruh beberapa level daging itik Manila dan tepung sagu terhadap komposisi kimia dan sifat organoleptik bakso. Jurnal Sain Peternakan Indonesia, 3 (1): 30-34.

N R C. 1994. Nutrient Requirement of Poultry. Ninth Revise Edition. Printing and Publishing National Academy of Science. Washington.

Samudera, R. dan A. Hidayatullah. 2008. Warna kulit, lemak abdomen dan lemak karkas itik alabio (Anas playhyhincos Borneo) jantan akibat pemberian azola dalam ransum. Animal Production, 10 (3): 164-167.

Sandi, S., R. Palupi dan Amyesti. 2012. Pengaruh penambahan ampas tahu dan dedak fermentasi terhadap karkas, usus, dan lemak abdomen ayam broiler. Arginak, 2 (1): 1-5.

Suparjo, S., Syarif dan Rasputi, 2003. Pengaruh penggunaan pakan berserat kasar tinggi dalam ransum ayam pedaging terhadap organ dalam. Jurnal IImiah IImu IImu Peternakan 6(1): 42-48.

Sutardi, T. 1997. Peluang dan tantangan pengembangan ilmu-ilmu nutrisi ternak. Orasi Ilmiah Guru Besar Tetap IImu Nutrisi, Fakultas Peternakan Institut Pertanian Bogor, Bogor.

Tanwiriah, S. Syarif dan Rasupati. 2006. Pengaruh tingkat protein dalam ransum terhadap performa entok lokal pada priode pertumbuhan. Seminar Nasional Teknologi Peternakan dan Veteriner, Bogor.

Trisnadewi, A.A.A.S., I.G.N.G. Bidura, A.T. Umiarti dan A.W. Puger. 2000. Pemanfaatan ampas tahu terfermentasi dalam ransum untuk turunkan akumulasi lemak dan kolestrol tubuh itik. Majalah Ilmiah Peternakan, 18 (2): 55-60. 